\title{
ANALISIS DETERMINAN PENDAPATAN USAHA KECIL DI KABUPATEN LABUHANBATU
}

\author{
Zulkarnain Nasution \\ Dosen Tetap Sekolah Tinggi Ilmu Ekonomi (STIE) Labuhanbatu
}

\begin{abstract}
ABSTRAK
Tujuan utama dari penelitian ini adalah untuk mengetahui atau membedakan faktor-faktor yang mempengaruhi pedagang kecil di Kabupaten Labuhanbatu. Data yang digunakan dalam penelitian ini adalah data sekunder yang dikumpulkan dari lapangan. Sampling yang digunakan adalah simple random sampling dengan mengambil 150 responden dari total populasi pedagang kecil yang tersebar di seluruh kecamatan di Kabupaten Labuhanbatu. Model yang digunakan dalam penelitian ini adalah model ekonometrik dan metode yang digunakan adalah Ordinary Least Square (OLS). Koefisien determinasi (R2) menunjukkan bahwa semua variabel seperti modal kerja, tingkat pendidikan, jumlah pengusaha dan jam kerja dapat menggambarkan semua variasi pendapatan yang diterima pedagang kecil sebesar 67 persen, sedangkan 33 persen bukan modelnya. Oleh karena itu, uji $F$ (all over test) menunjukkan bahwa semua variabel independen dapat mempengaruhi variabel dependen secara signifikan. Hasil penelitian menunjukkan bahwa variabel modal kerja berpengaruh signifikan terhadap total pendapatan yang diterima pedagang kecil pada tingkat $\alpha=5 \%$. Sementara itu, jumlah pengusaha, jam kerja, tingkat pendidikan signifikan pada $\alpha=10 \%$.
\end{abstract}

Kata kunci: $\quad$ Pedagang Skala Kecil, Modal Kerja, Tingkat Pendidikan, Jam Kerja Dan Jumlah Pengusaha.

\section{PENDAHULUAN}

Kendala klasik seputar usaha kecil dan rumah tangga di Indonesia yang sering dibicarakan sampai saat ini adalah soal kekurangan modal, tenaga kerja, di samping peralatan atau teknologi dan juga pemasaran. Sehingga muncul pertanyaan yang paling esensial dari dampak permasalahan tersebut yaitu bagaimana sektor usaha kecil dalam negeri dapat didorong menjadi sektor usaha berskala besar sehingga memberikan tingkat pendapatan masyarakat yang cukup baik.

Sejak tahun 1983, pemerintah secara konsisten telah melakukan berbagai upaya deregulasi sebagai upaya penyesuaian struktural dan restrukturisasi perekonomian. Kendati demikian, banyak yang mensinyalir deregulasi di bidang perdagangan dan investasi tidak memberi banyak keuntungan bagi perusahaan kecil dan menengah bahkan sebaliknya justru perusahaan besar dan konglomerat yang mendapat keuntungan. Studi empiris membuktikan bahwa pertambahan nilai tambah ternyata tidak dinikmati oleh perusahaan skala kecil, sedang, dan besar, namun justru perusahaan skala konglomerat, dengan tenaga kerja lebih 


\section{Jurnal Ecobisma Vol 1 No. 12014}

100 orang yang menikmati kenaikan nilai tambah secara absolut (Kuncoro \& Abimayu, 1995).

Dalam konstelasi inilah perhatian untuk menumbuh kembangkan industri kecil dan rumah tangga yang menyerap banyak tenaga kerja. Kecenderungan menyerap banyak tenaga kerja umumnya membuat banyak industri kecil dan rumah tangga juga intensif dalam menggunakan sumberdaya alam lokal. Apalagi lokasinya banyak di pedesaan, pertumbuhan industri kecil akan menimbulkan dampak positif terhadap peningkatan jumlah tenaga kerja, pengurangan jumlah kemiskinan, pemerataan dalam distribusi pendapatan, dan pembangunan ekonomi di pedesaan (Simatupang,et al, 1994; Kuncoro, 1996). Dari sisi kebijakan, industri rumah tangga jelas perlu mendapat perhatian karena tidak hanya memberikan penghasilan bagi sebagian besar angkatan kerja, namun juga merupakan ujung tombak dalam upaya mengentaskan kemiskinan. Di pedesaan, peran penting industri kecil dan rumah tangga memberikan tambahan pendapatan (Sandee et all, 1994), merupakan seedbed bagai pengembangan industri dan sebagai pelengkap produksi pertanian bagi penduduk miskin (Weijland, 1999).

Dewasa ini salah satu upaya yang sudah dilakukan pemerintah sebagai suatu strategi dalam pengembangan usaha kecil adalah dengan memperhatikan antara keseimbangan, penguasaan teknologi dan meningkatkan peranan swasta. Strategi itu ditunjang dengan kebijakan ekonomi yang dapat mendorong upaya tersebut, di antaranya dengan sistem kemitraan antara industri besar, menengah dengan usaha kecil/ industri rumah tangga dan koperasi. Hal ini ditunjukkan oleh kenyataan tiga tahun belakangan ini, pertumbuhan unit usaha telah mencapai 61,5 ribu unit usaha, dengan kapasitas penyerapan tenaga kerja tambahan mencapai 869,3 ribu orang. (http://www.rad.net.id/online/mediaind/publik/11/23/MI16-23.html).

Dampak dari bantuan yang diberikan oleh pengusaha besar atau menengah kepada usaha kecil dan koperasi, langsung mendapat tanggapan yang positif dari barbagai pihak. Terutama pihak yang paling berkepentingan di sini, yaitu pengusaha usaha kecil dan koperasi, yang langsung merasakan problematik tersebut.

Kondisi riil yang ditunjukkan oleh hampir seluruh daerah kabupaten/ Kota di Indonesia menggambarkan bahwa kegiatan usaha kecil yang hampir seluruhnya berada di daerah Kabupaten/Kota selalu dilanda fenomena sulit berkembang dikarenakan banyaknya masalah yang mereka hadapi mulai dari permasalahan ketersedian modal dan tingkat kemampuan SDM pekerja yang relatif kurang memadai. Misalnya sektor industri kerajinan dan produksi hasil pertanian, seperti kerajinan rotan, kayu, keramik gerabah, bata, dan mkanan, merupakan sektor industri yang memiliki potensi ekspor, karena itu sangat berprospek apaila dapat dikembangkan, terutama industri kerajinannya.

Dalam sebuah artikel (Budianto, 2007) dijelaskan bahwa dalam beberapa tahun terakhir dapat dilihat banjirnya produk pangan dari luar negeri yang banyak ragamnya, mulai yang bermitra dengan perusahaan di Indonesia atau lebih dikenal dengan toll manufacturing, produk impor legal dan produk ilegal. Jika dicermati dengan baik, ternyata produk tersebut tidak hanya dihasilkan oleh industri besar akan tetapi juga dihasilkan oleh usaha kecil. Semuanya mempunyai kesamaan yaitu memiliki penampilan produk yang prima, baik dari segi kemasan maupun kualitas produknya. Kemasan produk impor tersebut mempunyai desain yang menarik dan terbuat dari bahan yang baik sehingga dapat menarik minat 


\section{Jurnal Ecobisma Vol 1 No. 12014}

konsumen untuk membelinya. Dan satu keunggulan lagi adalah harganya yang sangat kompetitif.

Dengan demikian jelaslah bahwa sebelum pintu "Pasar Bebas" secara resmi dibuka industri-usaha kecil di Indonesia sudah mendapat persaingan yang cukup berarti terutama dalam hal pemasaran. Sebagai konsekwensinya jelaslah bahwa dunia Usaha kecil maupun mikro di Indonesia harus bergerak cepat demi mengimbangi persaingan yang sudah pasti datang beberapa tahun ke depan.

Pada sisi lain, peran pemerintah yang ditunjukkan dalam pasal 25 Undang-undang Nomor 5 Tahun 1995 tentang usaha kecil dan menengah mencakup beberapa bidang terutama dalam tujuannya memberikan dukungan dana maupun modal atau aspek pembiayaan bagi usaha kecil yang ada di Indonesia yakni terdiri dari ; Penyedian kredit perbankan, Pinjaman lembaga keuangan bukan bank, modal ventura, pinjaman dari dana penyisihan laba Badan Usaha Milik Negara (BUMN), Hibah dan jenis pembiayaan lainnya. Ini berarti bahwa dalam perspektif formal, Usaha Kecil seharusnya telah mendapatkan berbagai sumber modal yang mencukupi.

Kabupaten Labuhanbatu merupakan salah satu daerah yang memiliki potensi sumber daya alam yang cukup baik. Akan tetapi realita seperti masih rendahnya pendapatan yang diperoleh oleh pelaku usaha kecil di kecamatan se-Kabupaten Labuhanbatu masih banyak dijumpai, khususnya para pelaku usaha kecil yang tersebar di sekitar ibu kota Kabupaten Labuhanbatu. Hal ini sangat dimungkinkan terjadi karena pelaku usaha kecil yang didominasi oleh keluarga masih belum menggunakan teknologi yang efisien dan efektif sehingga produk yang dihasilkan pun belum dapat mengimbangi produk-produk yang dihasilkan oleh sektor usaha besar ataupun menengah. Dengan kata lain keberadaannya dalam menghadapi persaingan di era pasar bebas masih menjadi tanda tanya besar.

\section{Model Analisis}

Untuk mengidentifikasi faktor-faktor yang mempengaruhi pendapatan Usaha Kecildi kabupaten Labuhanbatudigunakan persamaan regresi linier berganda (multiple lenear regression). Variabel terikat (dependent variable) dalam penelitian ini adalah Pendapatan Usaha Kecil dan sebagai variabel bebas (independent variable) adalah Tingkat Pendidikan, Kredit Modal Kerja, Jumlah Tenaga Kerja dan Lama Bekerja. Untuk itu fungsi persamaan yang digunakan dalam penelitian ini adalah:

$\mathrm{Y}=\mathrm{f}\{\mathrm{MK}, \mathrm{TK}, \mathrm{LB}, \mathrm{TP}\}$

Selanjutnya fungsi tersebut dispesifikasikan ke dalam model logaritma sebagai berikut

$\log \mathrm{Y}=\alpha_{0}+\alpha_{1} \log \mathrm{MK}+\alpha_{2} \log \mathrm{TK}+\alpha_{3} \log \mathrm{LB}+\alpha_{4} \log \mathrm{TP}+\mu$

Dimana :

$\mathrm{Y} \quad=$ Pendapatan Usaha Kecil $(\mathrm{Rp})$

MK $\quad$ = Modal Kerja (Rp)

TK = Jumlah Tenaga Kerja (Orang)

LB $\quad=$ Lama Bekerja (Jam)

$\mathrm{TP} \quad=$ Tingkat Pendidikan (Tahun)

$\mu \quad=$ Kesalahan Pengganggu

$\alpha_{0, \alpha} 1, \alpha 2 \alpha 3, \alpha 4=$ Koefisien Regresi 


\section{Metode Analisis}

Metode analisis yang digunakan dalam penelitian ini adalah dengan Metode Ordinary Least Square (OLS). Hal ini digunakan untuk melihat elastisitas Variabel Independen terhadap Variabel Dependen Penelitian ini. Dan sebagai alat analisis untuk mengolah data adalah dengan menggunakan program Eviews versi 4,1. Metode ini banyak digunakan karena ;

1. Pengestimasian parameter dengan menggunakan metode ini akan menghasilkan parameter yang bersifat optimum.

2. Perhitungan dengan menggunakan metode ini cukup mudah jika dibandingkan dengan metode ekonometrika yang lain dan metode ini tidak membutuhkan banyak data.

3. Metode Kuadrat Terkecil ini banyak digunakan secara luas dalam hubungan ekoomi dan banyak menghasilkan keputusan ekonomi yang baik. Dengan demikian metode ini banyak digunakan pada waktu mengestimasi hubungan dalam metode Ekonometrika.

4. Teknik-teknik dalam metode kuadrat terkecil sangat mudah dipahami.

5. Metode kuadrat Terkecil adalah komponen yang penting dalam ekonometrika.

\section{Uji Validitas Data}

Uji validitas data dapat dilakukan terhadap pengujian validitas konstruksi, validitas isi dan validitas eksternal. Validitas konstruksi adalah aspek-aspek yang akan diukur berlandaskan teori tertentu. Hal ini dapat dikonsultasikan dengan para ahlinya. Setelah pengujian dilakukan kepada ahli kemudian akan dilanjutkan kepada anggota sampel sekitar 30 orang. Pengujian validitas konstruksi dilakukan dengan mengkorelasikan antar score item instrument. Apabila korelasinya rendah dan tidak signifikan maka instrumen dianggab tidak valid. Uji validitas ini dapat diukur dengan teknik korelasi product moment.

Sedangkan pengujian validitas isi adalah membandingkan antara isi instrumen dengan isi materi seperti seorang dosen memberi ujian di luar pelajaran yang ditetapkan, berarti instrumen ujian tersebut tidak valid. Pengujian ini dapat dilakukan kepada para ahli. Sedangkan validitas eksternal adalah cara membandingkan antara kriteria yang ada pada instrumen dengan fakta-fakta empiris yang terjadi di lapangan. Hal ini dapat dilakukan dengan mengujicobakan kepada sampel, kalau ditemukan perbedaan yang terlalu mencolok maka instrumen harus disesuaikan.

\section{Uji Reliabilitas Data}

Pengujian reliabilitas digunakan untuk menguji hasil pengukuran angket dapat dilakukan baik secara eksternal maupun internal. Secara ekternal dilakukan dengan testretest, equivalen dan gabungannya. Test-retest dilakukan dengan cara mencobakan instrumen beberapa kali kepada responden, jadi dalam hal ini instrumennya sama, respondennya sama dan waktunya yang berbeda. Reliabilitas diukur dari koefisien korelasi antara percobaan pertama dan yang berikutnya. Bila koefisien positif dan signifikan maka instrumen tersebut dinyatakan reliable. Sedangkan dengan pendekatan equivalen adalah pernyataan yang secara bahasa berbeda tetapi maksudnya sama. Pengujian reliabilitas instrumen untuk ini dapat dilakukan dengan cara mengkorelasikan hasil data yang diperoleh dari responden yang sama, waktunya sama, tetapi instrumennya berbeda. Pengujian validitas dan reliabilitas ini akan dilakukan sebelum melakukan penelitian yang sebenarnya. 


\section{Uji Penyimpangan Asumsi Klasik}

Ada beberapa permasalahan yang bisa terjadi dalam model regresi linier, yang secara statistik permasalahan tersebut dapat mengganggu model yang telah dilakukan, bahkan dapat menyesatkan kesimpulan yang diambil dari persamaan yang terbentuk. Untuk itu maka perlu melakukan uji penyimpangan asumsi klasik, yang terdiri dari (Insukindro, 2000).

\section{Uji Normalitas}

Pengujian Normalitas Data bertujuan untuk mengetahui apakah suatu variabel normal atau tidak. Normal disini dalam arti mempunyai distribusi data yang normal. Normal atau tidaknya berdasar patokan distribusi normaldari data dengan mean dan standar deviasi yang sama. Jadi uji normalitas pada dasarnya yakni melakukan perbandingan antara data yang kita miliki dengan data berdistribusi normal yang memiliki mean dan standardeviasiyang sama dengan data yang kita pakai.

Data yang mempunyai distribusi yang normal merupakan salah satu syarat dilakukannya parametric-test. Untuk data yang tidak mempunyai distribusi normal tentu saja analisisnya harus menggunakan non parametric test. Selain itu data yang mempunyai distribusi secara normal berarti mempunyai sebaran yang normal pula. Dengan profil data semacam ini maka data tersebut dianggap bisa mewakili populasi.

Untuk mengetahuiapakahdata yang kita milikinormalatau tidak, secara kasat mata kita bisa melihat histogram dari data yang dimaksud, apakah membentuk kurva normal atau tidak.Tentu saja cara ini sangat subyektif.

Ujinormalitasdata yang digunakan di sini adalah uji Jarque Bera. Tahap uji Jarque Bera dengan menggunakanEviews secara ringkas adalah sebagai berikut :

a. Formulasi hipotesis

$H_{0}$ : distribusi $u_{t}$ normal

$H_{A}$ : distribusi $u_{t}$ tidak normal

b. Menentukan tingkat signifikansi (a)

c. Menentukan kriteria pengujian

$H_{0}$ ditolak jika prob. JB $£ a, H_{0}$ diterima jika prob. JB $>a$.

d. Kesimpulan

\section{Uji Multikolinieritas}

Interprestasi persamaan regresi linier secara implisit bergantung pada asumsi bahwa variabel-variabel bebas dalam persamaan tersebut tidak saling berkorelasi. Jika dalam sebuah persamaan terdapat multikolinieritas akan menimbulkan beberapa akibat, untuk itu perlu pendektesian multikolinieritas dengan besaran-besaran regresi yang di dapat, yakni :

1. Variasi besar (dari taksiran OLS)

2. Interval kepercayaan lebar (karena variasi besar maka standar error besar sehingga interval kepercayaan lebar).

3. Uji t (t-rasio) tidak signifikan, suatu variabel bebas yan signifikan baik secara substansi maupun secara statistik jika dibuat regresi sederhana, bisa tidak signifikan karena variasi besar akibat kolinieritas. Bila standar error terlalu besar maka besar pula kemungkinan taksiran koefesien regresi $\left(\mathrm{a}_{1}-\mathrm{a}_{4}\right)$ tidak signifikan.

4. $\mathrm{R}^{2}$ tinggi tetapi tidak banyak variabel yang signifikan dari Uji $t$ 


\section{Jurnal Ecobisma Vol 1 No. 12014}

5. Terkadang nilai taksiran koefesien yang didapat akan mempunyai nilai yang tidak sesuai dengan substansi, sehingga dapat menyesatkan interprestasi.

\section{Uji Heterokedastisitas}

Salah satu asumsi pokok dalam model regresi linear klasik adalah homokedastisitas atau varian yang sama. Salah satu metode yang dapatdigunakan ada tidaknya heterokedastisitas dalam satu varian error term suatu model regresi adalah metode Park.Heterokedastisitas dalam penelitian ini dideteksi dengan mengamati tampilan grafik (scatterplot). Tidak terdapatnya pola yang jelas dan titik-titik menyebar di atas dan di bawah angka 0 pada sumbu Y menunjukkan tidak terjadinya heterokedastisitas pada model regresi. Sedangkan adanya gejala heterokedastisitas ditunjukkan dengan adanya pola scatterplot yang dapat terlihat jelas. Jika model estimasi memiliki gejala heterokendastisitas maka kita dapat membuat kesimpulan yang salah dari interpretasi, karena estimasi OLS yang ada tidak lagi BLUE.

\section{Hasil Estimasi Model Penelitian}

Estimasi untuk mengetahui pengaruh variabel bebas (independent variable) terhadap variabel terikat (dependent variable) dilakukan dengan menggunakan menggunakan logaritma terhadap model regresi berganda. Hasil estimasi sebagai mana disajikan di bawah ini. D

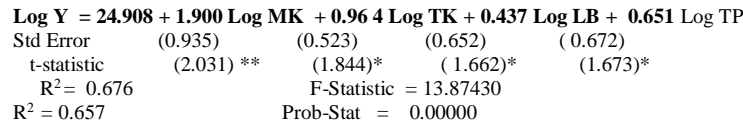

Keterangan :

**) signifikan pada $\alpha=5$ persen

*) signifikan pada $\alpha=10$ persen

Berdasarkan hasil estimasi di atas dapat menujukan bahwa $\mathrm{R}^{2}=0.676$ yang bermakna bahwa variabel independen modal kerja, tenaga kerja, lama bekerja dan tingkat pendidikan mampu menjelaskan variasi pendapatan pengusaha kecil sebesar $67.6 \%$ dan sisanya sebesar $32.4 \%$ dijelaskan oleh variabel lain yang tidak dimasukkan dalam modal estimasi.

Dari hasil uji simulatan (serempak) yang dilakukan melihat signifikansi secara bersama-sama variabel bebas dalam mempengaruhi variabel terikat (dependent variable). Dari estimasi tersebut diperoleh nilai F-Statistik sebesar 13.874 yang berarti secara bersamasama (modal kerja, tenaga kerja , lama bekerja dan tingkat pendidikan) dapat mempengaruhi tingkat pendapatan pengusaha kecil di daerah ini dengan selang keyakinan $95 \%$.

Pengujian dilakukan dengan membandingkan nilai F-tabel dengan F-hitung. Untuk degree of Freedom pada pengujian $\mathrm{F}$ adalah $\mathrm{v} 1=(\mathrm{k}-1)=5-1=4)$ dan $\mathrm{v} 2=(\mathrm{n}-\mathrm{k})=(150-4$ = 146), dijumpai F-tabel; pada $\alpha=0.05$ sebesar 4,02.

Sebagaimana yang telah dirumuskan pada bab sebelumnya, bahwa pengujian secara partial dilakukan dengan membandingkan nilai t- hitung dengan nilai t-tabel. Selain itu juga dilihat berdasarkan nilai signifikansi (sig) pada hasil estimasi.

Berdasarkan uji partial (Uji t-statistik) dapat diketahui variabel-variabel yang berpengaruh secara signifikan terhadap pendapatan pengusaha kecil di daerah ini. Pada jumlah sampel $(n)=150$, variabel bebas $(k)=5$. Koutsoyiannis,(1981) menjelaskan bahwa 


\section{Jurnal Ecobisma Vol 1 No. 12014}

besarnya $\mathrm{k}$ adalah variabel bebas termasuk konstanta. Dengan demikian $\mathrm{k}=5$ dijumpai Degree of Freedom $(\mathrm{DF})=150-5=145$. Pada $\mathrm{DF}=145$ dijumpai t-tabel pada pengujian dua ekor; $\alpha=0.005$ sebesar 2,576 dan pada $\alpha=0.05$ sebesar 1,1960 .

Berdasarkan hasil estimasi diperoleh nilai t-hitung variabel modal kerja sebesar 2.031 lebih besar dibandingkan 1.917 yang bermakna bahwa variabel modal kerja berpengaruh signifikan ( pada ; $\alpha=0.05$ ) terhadap pendapatan pengusaha kecil atau memiliki elastisitas lebih besar $>1$. Hal ini disebabkan bahwamayoritas pengusaha kecil menggunakan fasilitas bantuan keuangan dari pihak ketiga seperti bantuan kredit perbankan dan bantuan dari sumber-sumber lainnya.Selanjutnya t-hitung variabel waktu kerja sebesar 1.662 lebih besar dibandingkan 1.347 yang bermakna bahwa variabel waktu kerja berpengaruh signifikan (pada $\alpha=0.010$ ) terdapat peningkatan pendapatan pengusaha kecil. Variabel jumlah tenaga kerja mempunyai t-hitung sebesar 1.844 lebih besar dari t-tabel $\alpha=$ 0.010 sebesar 1.347 yang bermakna bahwa variabel jumlah pekerja berpengaruh signifikan pada $\alpha=0.10$ terhadap pendapatan pengusaha kecil.

Sementara itu, t-hitung variabel tingkat pendidikan sebesar 1.673 lebih besar dibandingkan nilai t-tabel pada $\alpha=0.10$ sebesar 1.347 dengan demikian dapat disimpulkan bahwa tingkat pendidikan signifikan mempengaruhi pendapatan pengusaha kecil.

\section{Uji Asumsi Klasik}

Mempertimbangkan bahwa dalam model regressi yang ingin dicapai adalah BestLinear Unbiased Estimator (BLUE) dan ada kalanya sering dijumpai dalam model regressi ( terutama regresi linear berganda) berbagai masalah terutama pelanggaran terhadap asumsi klasik, maka dalam penelitian ini dilakukan pengujian asumsi klasik berupa multikolinearitas dan heterokedastisitas.

\section{Uji Multikollinearitas}

Hasil interpretasi dari suatu model regresi berganda secara implisit sangat tergantung kepada asumsi bahwa antar variabel bebas(independent variables) yang terdapat dalam model tersebut tidak saling berkorelasi satu sama lainnya.

Dalam penelitian ini tidak terdapat multikolinearitas dianatara variabel independen. Hal ini dapat terlihat dari setiap koeffisien masing-masing variabel sesuai dengan hipotesia yang telah ditentukan.

Dari hasil pengujian multikolinearitas diantara masing-masing variabel independen dapat dilihat hasilnya sebagai berikut:

$\begin{array}{ll}\text { LOG }(\mathrm{MK}) & \mathrm{R}^{2}=0.252 \\ \text { LOG }(\mathrm{TK}) & \mathrm{R}^{2}=0.343 \\ \text { LOG }(\mathrm{LB}) & \mathrm{R}^{2}=0.179 \\ \text { LOG(TP) } & \mathrm{R}^{2}=0.379\end{array}$

Berdasarkan nilai $\mathbf{R}^{2}$ antar variabel bebas dalam regresi parsial di atas menunjukkan bahwa nilainya lebih kecil daripada nilai $\mathrm{R}^{2}$ dari hasil regresi model awal. Berdasarkan kepada rule of thumb menunjukkan bahwa tidak ditemukan adanya multikolinearitas.

\section{Uji Heterokedastisitas}

Dalam regresi berganda salah satu asumsi yang harus dipenuhi agar estimasi parameter dalam model tersebut bersifat BLUE adalah var $\left(\mathrm{u}_{\mathrm{t}}\right) \sigma^{2}$ (konstan), semua varian 


\section{Jurnal Ecobisma Vol 1 No. 12014}

mempunyai variansi yang sama.Pada kasus -kasus tertentu variansi ui kadang-kadang tidak konstan dan berubah-ubah.( Nachrowi dan Usman, 2002)

Berdasarkan hasil estimasi uji white heterocedasticity test diperoleh besarnya nilai Obs* R-Squared sebesar 12.577 dan bila dibandingkan dengan nilai $\chi^{2}$ Tabel sebesar 112.542 pada tingkat signifikansi $\alpha=5 \%$, maka dapat disimpulkan bahwa nilai Obs*Squared lebih kecil dan nilai $\chi^{2}$ Tabel (Obs*R-squared). Dengan demikian, hasil uji dengan menggunakan white heterocedasticity test tidak ditemukan masalah heterokedastisitas dalam model yang digunakan.

Tabel 1. Hasil Uji Heterokedastisitas

White Heterocedasticity Test

\begin{tabular}{llll}
\hline \hline F-statistic & 0.792285 & Probability & 0.785225 \\
Obs*R-squared & 12.57758 & Probability & 0.743852 \\
\hline \hline
\end{tabular}

\section{Uji Normalitas}

Uji normalitas ini dilakukan untuk mengetahui normal apa tidaknya faktor pengganggu yang dapat diketahui melaui uji JB -test. Uji ini menggunakan hasil estimasi residual danChi-Square Probability Distribution. Hasil estimasi yang dilakukan dengan uji JB test dapat dilihat pada lampiran.

Berdasarkan hasil estimasi JB test pada lampiran, diperoleh besarnya nilai JarqueBera normality test statistic sebesar 6.354 dan bila dibandingkan dengan nilai $\chi^{2}$ Tabel sebesar 112.542 pada tingkat $\alpha=5 \%$, maka dapat disimpulkan bahwa nilai JB test lebih kecil dan nilai $\chi^{2}$ Tabel. Hal ini berarti bahwa model yag digunakan dalam model tersebut mempunyai residual atau faktor pengganggu yang berdistribusi normal yang tidak dapat ditolak.

\section{Uji Linearitas}

Uji ini dilakukan untuk mengetahui apakah spesifikasi model yang digunakan adalah benar atau tidak. Apakah fungsi yang digunakan dalam model berbentuk linear atau tidak. Uji yang digunakan dalam peneltian ini adalah uji Ramsey ( Ramsey RESET Test).

Berdasarkan hasil estimasi Ramsey test pada lampiran, diperoleh hasil nilai $\mathrm{F}$ hit sebesar 0.0874 dan bila dibandingkan dengan nilai $\mathrm{F}_{\text {tabel }}$ sebesar 2.496 pada tingkat $\alpha=$ $5 \%$, maka dapat disimpulkan bahwa nilai $\mathrm{F}$ hit lebih kecildari $\mathrm{F}_{\text {tabel. }}$ Oleh karena itu, berdasarkan hasil uji Ramsey dapat disimpulkan bahwa model yang benar spesifikasinya adalah model dalam bentuk linear atau persamaan dalam bentuk linear.

\section{Kesimpulan}

1. Model yang digunakan dalam mengestimasi determinan pengusaha kecil di Kabupaten Labuhanbatu sangat baik, karena model terbebas dari pelanggaran asumsi klasik, juga karena variasi kemampuan variabel-variabel penjelas dalam menjelaskan pendapatan pengusaha kecil tergolong tinggi. Dengan tingkat $\mathrm{R}^{2}=0.676$ dapat disimpulkan bahwa dari segi uji kesesuaian (Test of goodness of fit) cukup baik, dan hanya 0.324 persen 


\section{Jurnal Ecobisma Vol 1 No. 12014}

dari determinan yang mempengaruhi pendapatan pengusaha kecil dijelaskan oleh variabel lain yang tidak dimasukkan dalam model penelitian.

2. Variabel Modal kerja berpengaruh positif dan signifikan pada $\alpha=5 \%$ terhadap pendapatan pengusaha kecil. Hal ini disebabkan bahwa fasilitas modal yang digunakan oleh pengusaha kecil berasal dari modal sendiri dan pinjaman dari pihak ketiga seperti kredit perbankan dan sumber-sumber lainnya. Sementara variabel lain yang mempengaruhi pendapatan usaha kecil adalah variabel tenaga kerja, Jumlah jam kerja dan variabel tingkat pendidikan yang signifikan pada $\alpha=10 \%$.

3. Berdasarkan uji serempak (simultan) variabel-variabel eksplanatori yang digunakan berpengaruh sangat signifikan pada $\alpha=1 \%$ terhadap pendapatan usaha kecil di Kabupaten Labuhanbatu. Dari koefisien masing-masing variabel, maka dapat disimpulkan bahwa tingkat elastisitas faktor-faktor yang mempengaruhi pendapatan pengusaha kecil di Kabupaten Labuhanbatu cukup elastis.

\section{Saran-Saran}

1. Pemerintah Daerah Kabupaten Labuhanbatu terutama Dinas UKM dan Koperasi agar lebih aktif memberikan penyuluhan kepada pengusaha kecil dalam rangka meningkatkan produksi sekaligus meningkatkan pendapatan. Selain itu perlu memperhatikan perkembangan modal pengusaha kecil dengan jalan memberikan bantuan kredit sehingga upaya-upaya untuk meningkatkan kemampuan pengusaha kecil dapat berkembang dengan baik.

2. Sebagaimana koefisien determinasi sebesar 0,676 yang berarti ada sekitar 0,324 faktorfaktor lain yang mempengaruhi pendapatan pengusaha kecil yangtidak dimasukkan ke dalam model penelitian ini. Kepada peneliti lain disarankan untuk mengidentifikasi variabel-variabel lain yang dapat mempengaruhi pendapatan pengusaha kecil.

\section{DAFTAR PUSTAKA}

Nafziger Wayne, E, 1997, The Economics of Developing Contries, $3^{\text {rd }}$ Edition, ISBN 0-13573460-6, Prentice Hall Inc.

Salvatore, Dominick, 2006, Theory and Problem f Micro Economic Theory, $3^{\text {rd }}$ Edition. Alih Bahasa oleh Rudi Sitompul, Penebit Erlangga, Jakarta.

Samuelson, Paul, A dan Nordhaus D, William, 1992, Ekonomi, Edisi 12 Jilid 2, Penerbit Erlangga, Jakarta.

Sukirno, Sadono, 2005, Makroekonomi Modern, Raja Grafindo Persada, Jakarta.

Sunyoto, Danang, 2007, Analisis Regresi dan Korelasi Bivariat, Ringkasan dan Kasus, Amara Books, Jakarta.

Todaro, P, Mikael, 2000, Pembangunan Ekonomi di Dunia Ketiga.Jakarta: Erlangga. 


\section{Jurnal Ecobisma Vol 1 No. 12014}

Triyuwono, Iwan dan Ahmad Erani Y 2003, Emansipasi Nilai Lokal Ekonomi dan Bisnis Pasca Sentralisasi Pembangunan, Bayumedia Publishing, Malang.

Wahyu A.P, Paidi H, 2007, Pedoman Praktis Penggunaan Eviews Dalam Ekonometrika, USU Press, Medan.

Wijaya, Farid, 1991, Perkreditan, Bank dan Lembaga-lembaga Keuangan, Edisi Pertama, BPFE, Yogyakarta.

http://www.rad.net.id/online/mediaind/publik/11/23/MI16-23.html, Diakses Pada Tanggal 17 November 2008 Pukul 16.24 WIB. 